\title{
Validasi Islamic Scale of Wisdom - Academic Version dengan San Diego Wisdom Scale dan PAPI-Kostick
}

\section{Fani Eka Nurtjahjo, Ahmad Rusdi, Maudista Widi Anggraeni, Immawati Hanifah, Farida Nur Ummi, Hanum Azizah Destyaputri, Aziza Zulfa Hardiana}

Jurusan Psikologi, Fakultas Psikologi dan Ilmu Sosial Budaya, Universitas Islam Indonesia, Yogyakarta

\begin{abstract}
Abstrak. Keberadaan Islamic Scale of Wisdom-Academic Version (ISM-AV) menjadi sebuah kebutuhan untuk mengetahui sejauh mana seseorang menilai keseimbangan dirinya sendiri dalam menggunakan akalnya untuk melahirkan tindakan/ sikap yang baik, dalam konteks akademik. Penelitian ini untuk memvalidasi ISW-AV menggunakan kriteria eksternal, yaitu San Diego Wisdom Scale (SD-WISE), dan PAPI-Kostick (hanya dipakai aspek: peran kepemimpinan (leadership role), kebutuhan mengendalikan orang lain (need to control others), ketenangan dalam membuat keputusan (ease in decision making), serta tipe berpikir teroretis (theoretical type). Proses validitas konten yang melibatkan sepuluh panelis berkualifikasi telah menjamin bahwa butir yang digunakan pada skala ini kebanyakan relevan (CVI > .80). Hasil studi kedua yang melibatkan 125 responden mahasiswa, menemukan bahwa ISW-AV ini memiliki kesamaan konstruk dengan skala kebijaksanaan yang baku (SD-WISE) $(r=.550, p<0.01)$. Selanjutnya hasil studi ketiga dengan melibatkan 666 mahasiswa menemukan bahwa ISW-AV berkorelasi positif dengan leadership role ( $r=.261)$, need to control others $(r=.232)$, dan ease in decision making ( $r=.114)$, namun berkorelasi negatif dengan theoritical type $(r=-.117)$. Temuan ini menunjukkan bahwa kebijaksanaan tidak sama dengan kecerdasan teoritik, justru lebih dekat pada keterampilan kepemimpinan sosial. Sebagai kesimpulan, skala ini dapat digunakan untuk kepentingan penelitian selanjutnya. Untuk pengembangan skala ini, proses penormaan dan penyusunan short form akan sangat berguna untuk melengkapi fitur dari skala ini.
\end{abstract}

Kata Kunci: kebijaksanaan akademik, kebijaksanaan, kebutuhan untuk mengontrol, kepemimpinan, pengambilan keputusan

\section{Validation of Islamic Scale of Wisdom - Academic Version with San Diego Wisdom} Scale and Papi-Kostick

\begin{abstract}
The existence of Islamic Scale of Wisdom-Academic Version (ISM-AV) becomes a necessity to know the extent to which a person assesses his balance in using his mind to produce good actions/attitudes, in an academic context. This study was to validate ISW-AV using external criteria, namely SD-WISE, and PAPI-Kostick (only used aspects: leadership role), need to control others, ease in making decisions, and the theoretical type of thinking. The content validity process involving ten qualified panelists has guaranteed that the items used on this scale are most relevant $(\mathrm{CVI}>\mathrm{.80})$. The results of the second study involving 125 student respondents, found that the ISW-AV had similar constructs to the standard wisdom scale (SD-WISE) $(r=.550$, $p<0.01)$. Furthermore, the results of the third study involving 666 students found that ISW-AV was positively correlated with leadership roles $(r=.261)$, the need to control others $(r=.232)$, and ease in decision making $(r=.114)$, but negatively correlated with the theoretical type $(r=$ -.117). This finding shows that wisdom is not the same as theoretical intelligence, it is closer to social leadership skills. In conclusion, this scale can be used for further research purposes. For the development of this scale, the process of normalizing and compiling a short form will be very useful to complement the features.
\end{abstract}

Keywords: academic wisdom, decision making, leadership, need to control, wisdom.

Korespondensi: Fani Eka Nurtjahjo. Email: fani.eka@uii.ac.id 
Kajian-kajian saintifik mengenai variabel-variabel kebijaksanaan (wisdom) telah banyak dikembangkan dalam beberapa dekade terakhir (Kim \& Knight, 2015; Roemer \& Orsillo, 2012; Thomas et al., 2017). Ketika berbicara tentang psikologi positif dan kesejahteraan (well-being), variabel kebijaksanaan ini memegang peranan penting di setiap rentang kehidupan manusia dewasa (Lopez \& Snyder, 2004; Mir \& Younas, 2015; Webster et al, 2014). Hal ini menunjukkan urgensi membahas variabel kebijaksanaan dalam rangka meningkatkan peradaban manusia (Grossmann, 2017). Bahkan dalam konteks akademik dan kepemimpinan, variabel kebijaksanaan ini dikaitkan dengan variabel-variabel lain yang turut berperan dalam proses regulasi dan penggunaan kecerdasan untuk melahirkan sikap dan perilaku yang dibutuhkan (Sternberg, 2001, 2003, 2009). Dalam sebuah studi bahkan muncul pemikiran menarik, bahwa tugas intelektual dasar dari penyelidikan ilmiah di dunia akademik seharusnya berfungsi untuk menjadi pemecah masalah-masalah sosial dan kemanusiaan, dengan menggunakan pendekatan kebijaksanaan, ketimbang hanya menggunakan pendekatan pengetahuan semata (Maxwell, 2007). Dengan demikian, pelibatan kebijaksanaan di dalam dunia akademik menjadi penting, bukan hanya dalam tataran konsep, melainkan dalam hal integrasi dan aplikasinya pada proses pembelajaran dan evaluasi hasil belajar.
Salah satu kebutuhan yang muncul dalam evaluasi proses implementasi sebuah program adalah pengukuran yang valid dan reliabel. Seperti telah diketahui sebelumnya, bahwa kajian tentang kebijaksanaan ini masih terus berkembang meski tidak sepopuler variabel psikologi positif lainnya. Namun demikian, muncul masalah besar dengan tersedianya instrumen pengukuran, yaitu masih minimnya instrumen yang kompatibel untuk digunakan dalam pengukuran kebijaksanaan dalam konteks akademik saat ini. Masalah lainnya muncul ketika alat ukur yang ada kurang tepat dalam hal konstruk teoretisnya dalam mengukur populasi yang memiliki perbedaan budaya. Sebagai contoh, masyarakat muslim yang memiliki populasi mayoritas yang besar, membutuhkan konstruk pengukuran yang berbeda dengan populasi agama yang lain karena suatu konsep ajaran agama yang dianut masyarakat tertentu, akan membentuk kepribadian masyarakat tersebut (Smither \& Khorsandi, 2009). Kebijaksanaan dalam tradisi barat berbeda dengan kebijaksanaan dalam tradisi timur dan tradisi Islam. Oleh karena itu, ISW-AV ini disusun berdasarkan keprihatinan terhadap masalah-masalah tersebut (Nurtjahjo \& Rusdi, 2018).

ISW-AV sebagai alat ukur yang baku telah mengalami beberapa validasi. Pada-Studi sebelumnya, ISW-AV ini telah melalui pengujian konsistensi internal, uji analisis faktor, serta validasi berdasarkan kriteria eksternal dengan berbagai alat ukur seperti Academic Dishonesty 
Scale (ADS) $(r=-.190, p<.01)$, Moral Disengagement Scale (MDS) $(r=-.227, p<.01)$, Meaning in Life Questionnaire (MLQ) ( $r=.573$, $p<.01$ ), Islamic Religiosity pada sub skala Ethical Conduct Do dan Ethical Conduct Don't, serta 3DWS-12 (Nurtjahjo \& Rusdi, 2018). Namun demikian, pada studi sebelumnya ditemukan korelasi antara ISW-AV dan 3DWS12 yang tidak memuaskan $(r=.150, p<.01)$ dan meninggalkan persoalan metodologis yang ditindaklanjuti dengan melakukan pengujian dengan skala kebijaksanaan lain ataupun instrumen lain yang secara konsep lebih koheren dan lebih bervariasi (Nurtjahjo \& Rusdi, 2018). Oleh karena itu, penelitian ini bertujuan untuk melakukan validasi ISW-AV menggunakan parameter baku yang lain, yaitu San Diego Wisdom Scale (SD-WISE), serta aspek-aspek dalam tes PAPI-Kostick seperti peran kepemimpinan $(\mathrm{L}=$ leadership role $)$, kebutuhan mengendalikan orang lain $(\mathrm{P}=$ need to control others), ketenangan dalam membuat keputusan ( $\mathrm{I}=$ ease in decision making), serta tipe berpikir teoretis ( $\mathrm{R}=$ theoretical type). Pemilihan PAPI-Kostick sebagai variabel eksternal pembanding dilakukan karena PAPIKostick merupakan inventori kepribadian yang lazim digunakan di Indonesia, terutama dalam hal penilaian kepribadian dan sikap kerja (Cemani et al, 2013). Selain itu, SD-WISE juga dipilih sebagai variabel kriteria eksternal dalam pengujian validasi penelitian ini karena memiliki konstrak yang mirip. Dalam upaya perbaikan berkelanjutan validitas konten ISW-
$\mathrm{AV}$, dilakukan pula uji butir dengan meminta kepada sejumlah panelis ahli untuk menilai relevansi setiap butir.

Pengukuran mengenai kebijaksanaan ini telah memiliki beberapa alat ukur sebelumnya seperti 3DWS-12 dan SD-WISE (Thomas et al., 2017, 2019). Penelitian sebelumnya telah mencoba untuk melakukan uji korelasi dengan 3DWS-12, dan pada penelitian kali ini uji validasi dilakukan dengan kriteria eksternal dengan mengkorelasikan ISW-AV dengan SD-WISE. Disamping itu, dilakukan pengujian lain terhadap ISW-AV dengan mengkorelasikan antara ISW-AV dan beberapa kebutuhan dan peran yang terdapat dalam inventori kepribadian PAPI-Kostick.

\section{Islamic Scale of Wisdom - Academic Version (ISW-AV)}

ISW-AV ini dibangun di atas pemahaman bahwa pengukuran terhadap masyarakat muslim semestinya didasarkan pada konstruk teori yang sesuai dengan budaya keislaman. Dasar teori ISW-AV diambil dari cendekiawan muslim Ibn Miskawaihò (2011) yang memandang bahwa kebijaksanaan (hikmah) merupakan sebuah konsep yang lahir dari keadilan dalam penggunaan akal. Kebijaksanaan merupakan sikap pertengahan antara melampaui batas dan bodoh/ ceroboh. Oleh karena itu, kebijaksanaan terkait dengan kecerdasan dan penggunaan akal, namun juga erat kaitannya dengan religiusitas atau keimanan seseorang dalam menyikapi sesuatu. Pada studi sebelumnya, ISW-AV telah melalui uji 
validitas berdasarkan struktur internal melalui pengujian analisis faktor dan mendapatkan nilai KMO sebesar .913 serta loading faktor berkisar dari .52 hingga .90 dengan rerata sebesar .695 (Nurtjahjo \& Rusdi, 2018). Dalam pengujian lanjutan, didapatkan enam komponen dari ISWAV dengan total variance explained sebesar $66.73 \%$, yaitu: (a) comprehension, (b) control, (c) problem solving, (d) scholastic, (e) fast reasoning, dan (f) stability dengan uji konsistensi internal masing-masing dimensi dengan nilai Alpha Cronbach berkisar antara .327 hingga .833 dengan rata-rata sebesar .635 (Nurtjahjo \& Rusdi, 2018).

\section{San Diego Wisdom Scale (SD-WISE)}

SD-WISE disusun berdasarkan pemahaman model trait psikologis dan neurobiologis yang kebanyakan data berasal dari negara Barat (Thomas et al, 2019). SDWISE dari Thomas et al (2019) awalnya terdiri dari enam komponen kebijaksanaan, diantaranya adalah: (a) pengetahuan umum tentang kehidupan dan pengambilan keputusan sosial - kemampuan untuk memberikan nasihat yang baik, pengetahuan hidup, dan keterampilan hidup; (b) regulasi emosional - mempengaruhi regulasi dan pengendalian diri; (c) perilaku prososial misalnya, empati, kasih sayang, altruisme, dan rasa keadilan; (d) wawasan - kemampuan dan keinginan untuk memahami diri sendiri dan tindakan seseorang pada tingkat yang dalam; (e) relativisme nilai (toleransi untuk nilai yang berbeda) - tidak menghakimi dan menerima sistem nilai lain; dan (f) ketegasan - kemampuan untuk membuat keputusan yang cepat dan efektif (Bangen et al., 2013; Meeks \& Jeste, 2009). Enam komponen ini dikuatkan di studi terpisah dengan menggunakan metode Delphi yang mengkonfirmasi bahwa keenamnya adalah merupakan kunci dalam mendefinisikan wisdom (Jeste et al., 2010). Selain itu, pendekatan putative neurobiologis juga dipertimbangkan dalam penyusunan alat ukur ini. Kerusakan parah pada area lokal tertentu di dalam otak turut mempengaruhi hilangnya karakteristik kepribadian yang terkait dengan kebijaksanaan (Meeks \& Jeste, 2009). Namun, pada pengujian analisis faktornya, keenam komponen ini mengalami perubahan bentuk dan berkembang menjadi (a) social advising, (b) emotional regulation, (c) pro-social behavior, (d) insight, (e) tolerance of divergent values, dan (f) deciciveness (Thomas et al., 2019). Konsistensi internal SD-WISE ditunjukkan dengan nilai reliabilitas Alpha Cronbach $=.72$ (Thomas et al, 2019). SD-WISE diuji kembali dengan menggunakan JesteThomas Wisdom Index dan didapat Alpha Cronbach sebesar 77 (Jeste et al, 2021). Dalam penelitian yang sama juga didapatkan bahwa hasil validitas alat ukur ini cukup memuaskan.

\section{Persamaan dan perbedaan ISW-AV dan SD- WISE}

Baik ISW-AV maupun SD-WISE ini memiliki beberapa kesamaan, diantaranya adalah keduanya sama-sama memandang kebijaksanaan sebagai sebuah konstruk yang 
memegang peranan penting dalam kesejahteraan diri individu. Keduanya mengambil dasar nilai-nilai baik (virtues) dari spiritualitas/ agama yang juga selaras dengan beberapa variabel penting dalam paradigma psikologi positif. Dengan kata lain, kedua alat ukur ini mengukur variabel psikologis yang sama, yaitu kebijaksanaan. Dalam hal pengujian properti psikometeriknya, kedua alat ukur ini sama-sama menggunakan kriteria eksternal sebagai uji validitasnya, terutama dengan alat ukur yang mengukur hal sama. ISW-AV dan SDWISE sama-sama menggunakan 3DWS-12 sebagai kriteria eksternal dalam pengujian validitas konvergennya.

Akan tetapi, dalam hal konstruk teori, kedua alat ukur ini memiliki konstruk dan dasar pemikiran yang berbeda. Sebagaian konsep dari SD-WISE terinspirasi dari Bible/ kitab suci umat nasrani (Thomas et al., 2019) dan juga pengambilan data mayoritas dilakukan pada masyarakat Barat. Sedangkan ISW-AV, merupakan dasar pemikiran dari cendekiawan muslim Ibn Miskawaihò (2011) yang corak pemikirannya sangat kental dengan nilai-nilai keIslaman. Perbedaan konstruk yang memiliki latar belakang budaya yang berbeda ini menjadi salah satu corak yang membedakan kedua alat ukur tersebut, terlebih keduanya belum pernah diujikan pada populasi yang saling silang. Hal ini membawa kesimpulan asumsi sementara bahwa SD-WISE belum tentu cocok jika dijadikan dasar pengukuran untuk masyarakat muslim, sementara ISW-AV juga belum tentu cocok jika dijadikan dasar pengukuran untuk masyarakat barat. Sementara dalam hal validitas diskriminan, kedua alat ukur ini menggunakan kriteria eksternal dengan skala yang berbedabeda.

\section{Perceptual and Preference Inventory Test (PAPI-Kostick)}

Tes PAPI-Kostick merupakan tes yang disusun pada awal tahun 1960-an di Amerika oleh seorang pakar Psikologi bidang Industri, Dr. Max Martin Kostick. Mulai masuk ke Indonesia sejak tahun 1990-an dan hingga kini sangat populer digunakan dalam berbagai kepentingan psikoasesmen di Indonesia, terutama dalam penilaian sikap kerja bagi pelamar pekerjaan, promosi jabatan, maupun untuk kepentingan talent mapping/ pemetaan bakat (Cemani et al., 2013). PAPI-Kostick ini merupakan sebuah inventori kepribadian yang diisi berdasarkan penilaian pribadi individu (self-report inventory). Tes ini terdiri dari 90 pasang pernyataan pendek yang mengungkap 20 faktor kepribadian. Kedua puluh faktor kepribadian ini kemudian dikelompokkan menjadi tujuh bidang: kepemimpinan (leadership), arah kerja (work direction), aktivitas kerja (activity), relasi sosial (social nature), gaya bekerja (work style), sifat temperamen (temperament), serta posisi atasan-bawahan (followership). Setiap bidang memiliki kebutuhan dan peran tertentu.

Bidang pertama berbicara tentang arah kerja (work direction). Terdapat tiga faktor yang termasuk bidang arah kerja, yaitu need to 
finish task (N), hard intense work (G), dan need to achieve (A). Bidang kedua adalah kepemimpinan (leadership), yang didalamnya memuat faktor leadership role (L), need to control others $(\mathrm{P})$, dan ease in decision making (I). Bidang ketiga adalah aktivitas (activity), yang memuat dua faktor yaitu pace (T) dan vigorous type $(\mathrm{V})$. Bidang keempat adalah mengenai relasi sosial (Social Nature), yang terdiri dari empat faktor yaitu need for closeness and affection (0), need to belong to groups (B), social extension (S), serta need to be noticed (X). Bidang kelima adalah gaya bekerja (work style) yang memuat tiga faktor yaitu organized type (C), interest in working with details (D), serta theoretical type (R). Bidang keenam adalah sifat temperamen (temperament) yang tterdiri dari tiga faktor, need for change (Z), emotional resistant (E), dan need to be forceful (K). Bidang ketujuh adalah tentang posisi atasan-bawahan (followership), need to support authority (F), need for rules and supervision (W).

Berdasarkan hal tersebut, diketahui ada beberapa faktor kebutuhan dan peran dalam inventori PAPI-Kostick yang sejalan dengan konsep ISW-AV, diantaranya adalah peran kepemimpinan (L), kebutuhan untuk mengendalikan orang lain (P), ketenangan dalam membuat keputusan (I), serta gaya bekerja tipe teoretis (R). Faktor peran kepemimpinan/ leadership role (L) menunjukkan seberapa jauh dan nyaman seseorang untuk menerima dirinya dalam peran sebagai pemimpin. Faktor kebutuhan untuk mengendalikan orang lain/ need to control others (P) menunjukkan seberapa jauh keinginan seseorang untuk mengendalikan, mendominasi, dan menggerakkan kekuatan orang lain untuk menyelesaikan tugas bersama. Faktor ketenangan dalam membuat keputusan/ ease in decision making (I) menunjukkan seberapa besar kemampuan seseorang dalam membuat keputusan yang tepat dalam situasi dilematis/ menekan, serta bertanggung jawab terhadap konsekuensi dari pilihannya tersebut. Faktor gaya kerja teoretis/ theoretical type (R) menunjukkan minat seseorang terhadap cara berpikir analitis dan konseptual, mengandalkan kemampuan mental dan berpikir abstrak, bukan respon terhadap kecepatan reaksi maupun inteligensi. PAPI-Kostick telah digunakan secara luas, dan ketika implementasinya diuji dalam sebuah sistem seleksi dan penempatan kerja didapat hasil yang valid (Cemani et al, 2013). Dengan demikian, diantara 20 faktor yang ada dalam PAPIKostick, keempat faktor inilah yang paling memiliki kemiripan konsep dengan ISW-AV, sehingga diambil sebagai variabel untuk menguji validitas ISW-AV.

\section{Metode}

Penelitian ini memiliki tiga skema studi yang berbeda, dimana pada setiap skema memiliki kriteria yang berbeda-beda sesuai dengan tujuannya. Pada studi 1 responden penelitian adalah delapan orang panelis yang memiliki latar belakang akademik dan pernah 
mengembangkan atau menguji alat ukur, sehingga memiliki pemahaman dasar mengenai konstruksi alat ukur psikologi. Pada studi 2, responden yang dilibatkan adalah 125 mahasiswa strata satu yang rentang usianya mulai dari 17-24 tahun, laki-laki dan perempuan dan beragama Islam. Begitu pula pada studi 3, kriteria umum yang ditetapkan dalam pemilihan responden hanya secara umum, yaitu mahasiswa S-1 (undergraduate), laki-laki dan perempuan, dan beragama Islam. Penetapan responden mahasiswa pada studi 2 dan 3 adalah karena ISW-AV ini mengukur kebijaksanaan dalam konteks akademik. Analisis datanya akan disesuaikan dengan skemanya. Berikut ini adalah penjelasan dari masing-masing studi.

\section{Studi 1}

Studi ini dilakukan sebagai upaya validasi konten pada penelitian ini. Ini tahap pertama yang penting, karena butir yang valid secara konten menunjukkan kesesuaiannya secara konsep. Oleh karena itu, validasi konten adalah proses pertama yang harus dilakukan.

\section{Metode}

Sejumlah delapan panelis terlibat dalam studi. Kriteria panelis adalah mereka yang pernah mengembangkan alat ukur atau menguji alat ukur. Seluruh panelis berpendidikan terendah adalah sarjana psikologi dan berpendidikan tertinggi adalah doktor di bidang psikologi. Ada dua opsi pilihan bagi panelis untuk menilai setiap butir, yaitu "relevan" atau "tidak relevan". Respon tersebut dihitung dengan pendekatan CVR (Content Validity Ratio) (Ayre \& Scally, 2014) dan CVI (Content Validity Index), (Shi et al., 2012).

\section{Hasil}

Hasil uji konten dari 10 orang panelis dapat dilihat pada tabel di bawah ini. Panelis diminta untuk menilai tujuh butir, $\mathrm{Ne}$ menunjukkan jumlah panelis yang merespon butir dengan jawaban "relevan". Berikut hasil jawaban dari panelis. 


\section{Tabel 1}

Uji Konten Panelis

\begin{tabular}{lccc}
\hline Butir & Ne & CVR & CVI \\
\hline Nomor 1 & 9 & .80 & .90 \\
Nomor 2 & 9 & .80 & .90 \\
Nomor 3 & 9 & .80 & .90 \\
Nomor 4 & 9 & .80 & .90 \\
Nomor 5 & 8 & .60 & .80 \\
Nomor 6 & 9 & .80 & .90 \\
Nomor 7 & 9 & .80 & .90 \\
Nomor 8 & 7 & .40 & .70 \\
Nomor 9 & 8 & .60 & .80 \\
Nomor 10 & 9 & .80 & .90 \\
Nomor 11 & 8 & .60 & .80 \\
Nomor 12 & 9 & .80 & .90 \\
Nomor 13 & 9 & .80 & .90 \\
Nomor 14 & 9 & .80 & .90 \\
Nomor 15 & 9 & .80 & .90 \\
Nomor 16 & 980 & .90 \\
Nomor 17 & 9 & .80 & .90 \\
Nomor 18 & 9 & .80 & .90 \\
Nomor 19 & 9 & .80 & .90 \\
Nomor 20 & 9 & .80 & .90 \\
Nomor 21 & 9 & .80 & .90 \\
Nomor 22 & 9 & .80 & .90 \\
Nomor 23 & 9 & .60 & .80 \\
Nomor 24 & 10 & 1 & 1 \\
Nomor 25 & 90 & .80 \\
Nomor 26 & 9 & 1 & 1 \\
\hline
\end{tabular}

\section{Pembahasan}

Hasil uji konten ditemukan bahwa hampir seluruh butir mendapatkan koefisien CVR sebesar .80 dan CVI sebesar .90. CVR sebesar .778 atau 5 dari 6 orang menganggap butir adalah relevan termasuk dalam kategori butir yang valid secara konten (Wilson et al, 2012). Dengan demikian, butir nomor 8, 9, 11,
23, dan 25 tidak valid dengan pendekatan CVR (CVR < .778). Namun, dengan pendekatan CVI, hanya butir nomor 8 yang tidak valid (CVI < .80) (Shi et al, 2012). Dengan demikian, secara meyakinkan butir 8 dieliminasi. Adapun untuk butir nomor 9, 11, 23, dan 25 dapat dipertahankan, karena masih memenuhi batas CVI. Namun, apabila dalam penggunaan 
penelitian berikutnya diperlukan eliminasi atau pemangkasan butir, maka butir nomor 9, 11, 23, dan 25 dapat diprioritaskan untuk dieliminasi.

\section{Studi 2}

Studi ini dilakukan sebagai upaya validasi konvergen (Carlson \& Herdman, 2012; Chadha, 2009; Krus \& Ney, 1978), yaitu melihat sejauh mana korelasi ISW-AV dengan SD-WISE (Thomas et al., 2019) yang keduanya memiliki konstruk yang sama, yaitu wisdom.

\section{Metode}

Partisipan terdiri dari 125 orang mahasiswa. Analisis korelasi digunakan untuk melihat hubungan kedua skala, yaitu ISW-AV dengan SD-WISE. Karena kedua skala ini adalah konstruk yang sama, diharapkan korelasi antara kedua skala lebih dari .50 $(r<.50)$.

\section{Hasil}

Berikut korelasi antara ISW-AV dengan SD-WISE baik pada level keseluruhan skala maupun pada tiap-tiap aspeknya.

\section{Tabel 2}

\section{Korelasi ISW-AV dan SD-WISE}

\begin{tabular}{|c|c|c|c|c|c|c|c|c|c|c|c|c|}
\hline Variabel & 1 & 2 & 3 & 4 & 5 & 6 & 7 & 8 & 9 & 10 & 11 & 12 \\
\hline 1. ISW-AV & - & & & & & & & & & & & \\
\hline 2. Com & $.785^{* *}$ & - & & & & & & & & & & \\
\hline 3. Con & $.815^{* *}$ & $.554^{* *}$ & - & & & & & & & & & \\
\hline 4. Prob & $.898^{* *}$ & $.797^{* *}$ & $.642^{* *}$ & - & & & & & & & & \\
\hline 5. Scho & $.822^{* *}$ & $.521^{* *}$ & $.563^{* *}$ & $.714^{* *}$ & - & & & & & & & \\
\hline 6. Fast & $.829^{* *}$ & $.537^{* *}$ & $.648^{* *}$ & $.659^{* *}$ & $.646^{* *}$ & - & & & & & & \\
\hline 7. Stab & $.835^{* *}$ & $.534^{* *}$ & $.626^{* *}$ & $.685^{* *}$ & $.668^{* *}$ & $.630^{* *}$ & - & & & & & \\
\hline 8. SD-WISE & $.550^{* *}$ & $.361^{* *}$ & $.467^{* *}$ & $.521^{* *}$ & $.369^{* *}$ & $.588^{* *}$ & $.427^{* *}$ & - & & & & \\
\hline 9. Soc & $.545^{* *}$ & $.355^{* *}$ & $.467^{* *}$ & $.515^{* *}$ & $.367^{* *}$ & $.583^{* *}$ & $.422^{* *}$ & $.999^{* *}$ & - & & & \\
\hline 10. Dec & $.551^{* *}$ & $.362^{* *}$ & $.467^{* *}$ & $.523^{* *}$ & $.369^{* *}$ & $.589^{* *}$ & $.427^{* *}$ & $1.000^{* *}$ & $.999^{* *}$ & - & & \\
\hline 11. Emo & $.541^{* *}$ & $.351^{* *}$ & $.473^{* *}$ & $.511^{* *}$ & $.355^{* *}$ & $.567^{* *}$ & $.432^{* *}$ & $.993^{* *}$ & $.994^{* *}$ & $.993^{* *}$ & - & \\
\hline 12. Ins & $.537^{* *}$ & $.347^{* *}$ & $.470^{* *}$ & $.509^{* *}$ & $.362^{* *}$ & $.578^{* *}$ & $.401^{* *}$ & $.994^{* *}$ & $.997^{* *}$ & $.994^{* *}$ & $.989^{* *}$ & - \\
\hline 13. Pro & $.543^{* *}$ & $.355^{* *}$ & $.451^{* *}$ & $.510^{* *}$ & $.377^{* *}$ & $.589^{* *}$ & $.420^{* *}$ & $.995^{* *}$ & $.995^{* *}$ & $.995^{* *}$ & $.981^{* *}$ & $.989^{* *}$ \\
\hline 14. Tol & $.564^{* *}$ & $.385^{* *}$ & $.460^{* *}$ & $.543^{* *}$ & $.372^{* *}$ & $.603^{* *}$ & $.443^{* *}$ & $.984^{* *}$ & $.977^{* *}$ & $.985^{* *}$ & $.967^{* *}$ & $.965^{* *}$ \\
\hline
\end{tabular}

\section{Pembahasan}

Berdasarkan korelasi di atas diketahui bahwa ISW-AV berkorelasi SD-WISE secara kuat baik pada level skala maupun pada aspekaspeknya yang semua koefisien korelasinya di atas $.50(r>.05)$. ini menunjukkan bahwa terdapat kesamaan konstruk antara ISW-AV dengan SD-WISE. Aspek fast reasoning adalah salah satu aspek ISW-AV yang paling berkorelasi dengan SD-WISE. Ini menunjukkan bahwa penggunaan nalar pada konsep kebijaksanaan Islam berkaitan erat dengan pikiran terbuka yang membuat seseorang bertoleransi atas perbedaan-perbedaan. Ini dapat disimpulkan dengan melihat korelasi yang paling besar dari tabel di atas, yaitu fast reasoning dan tolerance for divergent value ( $r=.603)$. Fast reasoning juga menjadi aspek ISW-AV yang banyak berhubungan paling kuat dengan aspek-aspek SD-WISE. 
Sebuah studi (Pasupathi \& Staudinger, 2001) menemukan bahwa mereka yang memiliki kemampuan penalaran moral yang lebih tinggi memperoleh lebih banyak pengetahuan terkait kebijaksanaan dan penilaian (judgement) seiring dengan bertambahnya usia, sedangkan mereka dengan tingkat kemampuan penalaran moral yang lebih rendah tidak memperoleh pengetahuan yang memadai. Pada studi lain (Huynh et al., 2017) ditemukan bahwa individu yang menggunakan pendekatan yang mengarah pada kebijaksanaan, menggunakan strategi penalaran yang berguna untuk penyelesaian konflik mereka maupun konflik orang lain. Ketika dihadapkan pada situasi yang dilematis, seringkali seseorang dihadapkan pada berbagai pilihan alternatif penyelesaian masalah, mulai dari yang logis dan rasional sampai yang tidak logis. Kebijaksanaan dalam penalaran situasi akan dapat membantu individu mengambil langkah pertama dalam menemukan jawaban sesuai dengan konteks yang dihadapi, dan penalaran yang bijak tidak hanya diperoleh seiring bertambahnya usia melainkan ada faktor-faktor lain yang turut berpengaruh didalamnya (Santos et al., 2017).

\section{Studi 3}

Studi dilakukan sebagai upaya validasi kriteria (Chadha, 2009), yaitu melihat sejauh mana korelasi ISW-AV dengan leadership role, need to control others, ease in decision making, dan theoritical type pada tes PAPI-Kostick.

\section{Metode}

Partisipan pada studi 3 ini melibatkan 666 orang mahasiswa. Analisis korelasi Spearmen digunakan untuk melihat hubungan kedua skala, karena skala PAPI-Kostick menghasilkan data ordinal.

\section{Hasil}

Berikut ini adalah hasil korelasi ISW-AV dan aspek-aspeknya dengan leadership role, need to control others, ease in decision making, dan theoritical type.

\section{Tabel 3}

Korelasi ISW-AV dengan Aspek PAPI-kostick

\begin{tabular}{|c|c|c|c|c|c|c|c|c|c|c|c|}
\hline Variabel & 1 & 2 & 3 & 4 & 5 & 6 & 7 & 8 & 9 & 10 & 11 \\
\hline 1. ISW_AV & - & & & & & & & & & & \\
\hline 2. Com & $.739^{* *}$ & - & & & & & & & & & \\
\hline 3. Scho & $.731^{* *}$ & $.622^{* *}$ & - & & & & & & & & \\
\hline 4. Prob & $.827^{* *}$ & $.634^{* *}$ & $.653^{* *}$ & - & & & & & & & \\
\hline 5. Fast & $.681^{* *}$ & $.435^{* *}$ & $.356^{* *}$ & $.555^{* *}$ & - & & & & & & \\
\hline 6. Con & $.632^{* *}$ & $.293^{* *}$ & $.251^{* *}$ & $.356^{* *}$ & $.321^{* *}$ & - & & & & & \\
\hline 7. Stab & $.598^{* *}$ & $.292^{* *}$ & $.406^{* *}$ & $.435^{* *}$ & $.237^{* *}$ & $.320^{* *}$ & - & & & & \\
\hline 8. Lead & $.261^{* *}$ & $.246^{* *}$ & $.206^{* *}$ & $.300^{* *}$ & $.258^{* *}$ & .051 & $.131^{* *}$ & - & & & \\
\hline 9. Need & $.232^{* *}$ & $.193^{* *}$ & $.170^{* *}$ & $.267^{* *}$ & $.237^{* *}$ & .029 & $.151^{* *}$ & $.400^{* *}$ & - & & \\
\hline 10. Ease & $.114^{* *}$ & $.131^{* *}$ & .051 & $.132^{* *}$ & $.198^{* *}$ & .028 & -.016 & $.293^{* *}$ & $.158^{* *}$ & - & \\
\hline 11. Theo & - & - & -.036 & - & - & - & -.041 & - & -.027 & - & - \\
\hline & $.117^{* *}$ & $.128^{* *}$ & & $.115^{* *}$ & $.172^{* *}$ & $.076^{*}$ & & $.220^{* *}$ & & $.262^{* *}$ & \\
\hline
\end{tabular}

Catatan. ${ }^{*} p<. .05 ;{ }^{* *} p<.01$; Com = Comprehension; Scho = Scholastic; Prob = Problem solving; Fast = Fast reasoning; Con = Control; Stab = Stability; Lead = Leadership role; Need = Need to control others; Ease = Ease in decision making; Theo = Theoritical type. 


\section{Pembahasan}

Berdasarkan hasil di atas, diketahui bahwa ISW-AV berkorelasi signifikan dengan leadership role, need to control others, ease in decision making, dan theoritical type, namun korelasinya bukan korelasi yang kuat. Hal ini bisa dipahami karena kedua skala bukan pada konstruk yang sama. Terdapat variabel yang paling besar hubungannya dengan ISW-AV, yaitu leadership role dan need to control others. Hal ini menunjukkan bahwa kebijaksanaan berkorelasi dengan ukuran-ukuran kepemimpinan. Sebuah studi yang melakukan analisis transkrip wawancara pemimpin yang dinominasikan sebagai orang bijak menunjukkan adanya tiga domain, yaitu: (a) insiden kearifan melibatkan kepemimpinan; (b) proses definisi hikmat menggambarkan insiden yang dilaporkan oleh pemimpin kebijaksanaan; dan (c) kebijakan terkait kepemimpinan lebih cenderung ditampilkan di masyarakat, dan di tingkat organisasi melalui memenuhi visi, memecahkan masalah, dan mendirikan organisasi; dimana dari ketiga domain tersebut merujuk pada satu kesimpulan bahwa ruang lingkup kebijaksanaan yang berhubungan dengan kepemimpinan sering kali melampaui organisasi individu, serta dapat memberikan efek positif ke wilayah masyarakat yang lebih luas (Yang, 2011). Dalam sebuah literatur muncul ide menarik untuk mengembangkan konsep kepemimpinan baru di era kompleks saat ini yang sebelumnya didominasi oleh rasionalitas, agar bertransformasi menjadi konsep kepemimpinan yang berlandaskan kebijaksanaan (Branson, 2009). Konsep kebijaksanaan dianggap lebih tepat sebagai gaya kepemimpinan kontemporer yang dapat memberikan kerangka kerja bagi pemimpin untuk menangani persoalan yang transenden melalui perubahan struktur ontoogis, tidak hanya sekedar mengandalkan pengetahuan yang luas (McKenna et al., 2009). Hal ini tentu semakin menguatkan pendapat bahwa kebijaksanaan/ wisdom memegang peranan penting dalam kepemimpinan, disamping faktor-faktor lain yang juga mempengaruhi.

Salah satu yang menarik dari temuan ini adalah korelasi negatif antara ISW-AV dengan theoritical type. Ini menunjukkan bahwa konsep ISW-AV yang dikembangkan dari Ibn Miskawaih cenderung pada konsep kebijaksanaan yang muncul dari akal praktis. Sebagaimana diketahui bahwa dalam konsep filsafat Islam, salah satunya pendapat Ibn Sina, bahwa akal terdiri dari akal teoritis dan akal praktis. Akal teoritis bertugas untuk mencari kebenaran, adapun akal praktis berfungsi untuk menerapkan pengetahuan dan mengendalikan jiwa (Gutas, 2012). Kebijaksanaan dalam hal ini berarti ada pada tataran praktis bukan pada tataran teoritis. Dalam arti lain, kebijaksanaan bukan tentang banyaknya pengetahuan, melainkan penggunaan dari pengetahuan tersebut. Dengan kata lain, kebijaksanaan dengan kecerdasan teoritik adalah tidak sama (Clayton, 1982; Grossmann et al., 2013). 


\section{Simpulan}

Penelitian ini mengkonfirmasi bahwa skala ini cukup dapat diandalkan untuk mengukur kebijaksanaan dalam konteks akademik. Proses validitas konten telah menjamin bahwa butir yang digunakan pada skala ini kebanyakan relevan. Skala ini juga menunjukkan ada kesamaan konstruk dengan skala kebijaksanaan yang baku. Beberapa variabel yang berkaitan dengan kepemimpinan berkorelasi dengan skala ini dan memenuhi kriteria yang diharapkan. Skala ini dapat digunakan untuk kepentingan penelitian.

\section{Saran}

Untuk pengembangan skala ini, proses penormaan dan penyusunan short form akan sangat berguna untuk melengkapi fitur dari skala ini.

\section{Referensi}

Ayre, C., \& Scally, A. J. (2014). Critical values for Lawshe's content validity ratio: Revisiting the original methods of calculation. Measurement and Evaluation in Counseling and Development, 47(1), 79-86. https:// doi.org/10.1177/0748175613513808

Bangen, K. J., Meeks, T. W., \& Jeste, D. V. (2013). Defining and assessing wisdom: A review of the literature. The American Journal of Geriatric Psychiatry, 21(12), 12541266. https://doi.org/10.1016/ j.jagp.2012.11.020

Branson, C. M. (2009). Leadership for an age of wisdom. In Leadership for an Age of Wisdom (pp. 157-163). Springer Netherlands. https://doi.org/10.1007/ 978-90-481-2996-6_10
Carlson, K. D., \& Herdman, A. O. (2012). Understanding the impact of convergent validity on research results. Organizational Research Methods, 15(1), 17-32. https://doi.org/10.1177/ 1094428110392383

Cemani, D. P., Soebroto, A. A., \& Wicaksono, S. A. (2013). Sistem pakar tes kepribadian papi kostick untuk seleksi dan penempatan tenaga kerja. MATICS, 2428. https://doi.org/10.18860/ matv0i0.2428

Chadha, N. K. (2009). Applied psychometry. SAGE Publications India. https://doi.org/ 10.4135/9788132108221

Clayton, V. (1982). Wisdom and intelligence: The nature and function of knowledge in the later years. International Journal of Aging and Human Development, 15(4), 315321. https://doi.org/10.2190/17tqbw3y-p8j4-tg40

Grossmann, I. (2017). Wisdom in context. Perspectives on Psychological Science, 12(2), 233-257. https://doi.org/ $10.1177 / 1745691616672066$

Grossmann, I., Na, J., Varnum, M. E. W., Kitayama, S., \& Nisbett, R. E. (2013). A route to wellbeing: Intelligence versus wise reasoning. Journal of Experimental Psychology: General, 142(3), 944-953. https://doi.org/10.1037/a0029560

Gutas, D. (2012). Avicenna: The metaphysics of the rational soul. The Muslim World, 102(3-4), 417-425. https://doi.org/ 10.1111/j.1478-1913.2012.01413.x

Huynh, A. C., Oakes, H., Shay, G. R., \& McGregor, I. (2017). The wisdom in virtue: Pursuit of virtue predicts wise reasoning about personal conflicts. Psychological Science, 28(12), 1848-1856. https://doi.org/ $10.1177 / 0956797617722621$

Jeste, D. V., Ardelt, M., Blazer, D., Kraemer, H. C., Vaillant, G., \& Meeks, T. W. (2010). Expert consensus on characteristics of wisdom: A delphi method study. Gerontologist. https://doi.org/10.1093/geront/gnq022 
Jeste, D. V., Thomas, M. L., Liu, J., Daly, R. E., Tu, X. M., Treichler, E. B. H., Palmer, B. W., \& Lee, E. E. (2021). Is spirituality a component of wisdom? Study of 1,786 adults using expanded San Diego Wisdom Scale (Jeste-Thomas Wisdom Index). Journal of Psychiatric Research, 132, 174-181. https://doi.org/10.1016/ j.jpsychires.2020.09.033

Kim, S., \& Knight, B. G. (2015). Adaptation of the three-dimensional wisdom scale (3D-WS) for the Korean cultural context. International Psychogeriatrics, 27(2), 267-278. https://doi.org/10.1017/ S1041610214002178

Krus, D. J., \& Ney, R. G. (1978). Convergent and discriminant validity in item analysis. Educational and Psychological Measurement, 38(1), 135-137. https:// doi.org/10.1177/001316447803800118

Lopez, S., \& Snyder, C. (2004). Positive psychological assessment/: A handbook of models and measures. https://doi.org/ 10.1037/10612-000

Maxwell, N. (2007). From knowledge to wisdom: The need for an academic revolution. London Review of Education, 5(2), 97115. https://doi.org/10.1080/ 14748460701440350

McKenna, B., Rooney, D., \& Boal, K. B. (2009). Wisdom principles as a meta-theoretical basis for evaluating leadership. The Leadership Quarterly, 20(2), 177-190. h t tp s: / / doi.org / 10.1016 / j.leaqua.2009.01.013

Meeks, T. W., \& Jeste, D. V. (2009). Neurobiology of wisdom: A literature overview. Archives of General Psychiatry, 66(4), $355 . \quad$ https://doi.org/10.1001/ archgenpsychiatry.2009.8

Meyer, L. N. (1998). Wisdom and the Well-Being of Humanity. Contemporary Philosophy, 20(1-2) 15-18.

Mir, H., \& Younas, M. (2015). Promoting wellbeing through positive psychology. I-Manager's Journal on Nursing, 36(4),
36-39. https://search-proquestcom.ezproxy.lib.swin.edu.au/docview/ 1782953984 ? a c c o un tid= $\begin{array}{llllllllllll}1 & 4 & 2 & 0 & 5 & \& & \mathrm{r} & \mathrm{f} & \mathrm{r} & \mathrm{i} & \mathrm{d}\end{array}=$ info $\% 3$ Axri\%2Fsid\%3Aprimo

Miskawaihò, I. (2011). Tahdhîb al-akhlâq (Politeness of ethics) ((al-Halâlî). Manshûrât al-Jamal.

Nurtjahjo, F. E., \& Rusdi, A. (2018). Developing the Islamic scale of wisdom: Academic version (ISW-AV). Middle East Journal of Positive Psychology, 4(1), 12-24. https:// middleeastiournalofpositivepsychology.org/ index.php/mejpp/article/view/62

Parse, R. R. (2014). More on Leadership. Nursing Science Quarterly, 27(1), 5-5. h t tp s: / / doi.org/10.1177/ 0894318413509719

Pasupathi, M., \& Staudinger, U. M. (2001). Do advanced moral reasoners also show wisdom? Linking moral reasoning and wisdom-related knowledge and judgement. International Journal of Behavioral Development, 25(5), 401-415. https:/ / d o i . o r g / 10.1080 / 016502501316934833

Roemer, L., \& Orsillo, S. M. (2012). Anxiety disorders: Acceptance, compassion, and wisdom. In Wisdom and compassion in psychotherapy: Deepening mindfulness in clinical practice. (pp. 234-248). Guilford Press.

Santos, H. C., Huynh, A. C., \& Grossmann, I. (2017). Wisdom in a complex world: A situated account of wise reasoning and its development. Social and Personality Psychology Compass, 11(10), e12341. https://doi.org/ $10.1111 / \mathrm{spc} 3.12341$

Shi, J., Mo, X., \& Sun, Z. (2012). Content validity index in scale development. Zhong Nan Da Xue Xue Bao. Yi Xue Ban = Journal of Central South University. Medical Sciences, 37(2), 152-155. https:// doi.org/10.3969/j.issn.16727347.2012.02.007 
Smither, R., \& Khorsandi, A. (2009). The implicit personality theory of Islam. Psychology of Religion and Spirituality, 1(2), 81-96. https://doi.org/10.1037/a0015737

Sternberg, R. J. (2001). Why schools should teach for wisdom: The balance theory of wisdom in educational settings. Educational Psychologist, 36(4), 227245. https://doi.org/10.1207/ S15326985EP3604_2

Sternberg, R. J. (2003). Wisdom, intelligence, and creativity synthesized. Cambridge University Press. https://doi.org/ 10.1017/CB09780511509612

Sternberg, R. J. (2009). Academic intelligence is not enough WICS/ : An expanded model for effective practice in school and later in life. Liberal Education and Effective Practice.

Thomas, M. L., Bangen, K. J., Ardelt, M., \& Jeste, D. V. (2017). Development of a 12-Item Abbreviated Three-Dimensional Wisdom Scale ( 3D-WS-12 ): Item Selection and Psychometric Properties. Assessment, 24(1), 71-82. https:// doi.org/10.1177/1073191115595714

Thomas, M. L., Bangen, K. J., Palmer, B. W., Sirkin Martin, A., Avanzino, J. A., Depp, C. A.,
Glorioso, D., Daly, R. E., \& Jeste, D. V. (2019). A new scale for assessing wisdom based on common domains and a neurobiological model: The San Diego Wisdom Scale (SD-WISE). Journal of Psychiatric Research, 108, 40-47. https:/ / d o i . o r g / 100.1016 / j.jpsychires.2017.09.005

Webster, J. D., Westerhof, G. J., \& Bohlmeijer, E. T. (2012). Wisdom and Mental Health Across the Lifespan. https://doi.org/ 10.1093/geronb/gbs121

Wilson, F. R., Pan, W., \& Schumsky, D. A. (2012). Recalculation of the critical values for Lawshe's content validity ratio. Measurement and Evaluation in Counseling and Development, 45(3), 197-210. https://doi.org/10.1177/ 0748175612440286

Yang, S. Y. (2011). Wisdom displayed through leadership: Exploring leadership-related wisdom. Leadership Quarterly, 22(4), 616-632. https://doi.org/10.1016/ j.leaqua.2011.05.004

Received 8 February 2021 Revised 16 June 2021 Accepted 31 July 2021 